А. Й. Наконечний, А. Р. Вергун, Т. І. Негрич, С. П. Ягело, І. О. Макагонов, О. М. Вергун, 3. М. Кіт, І. В. Шалько Львівський національний медичний університет імені Данила Галицького

\title{
АНТИПЛАГІАТНА СТРАТЕГІЯ ЕКСПЕРТИЗИ ДЕКІЛЬКОХ НАУКОВИХ ПРАЦЬ: АВТОРСЬКІ АЛГОРИТМИ ОДНОМОМЕНТНОЇ ПЕРЕВІРКИ ТЕЗ ДОПОВІДЕЙ СТУДЕНТІВ ТА МОЛОДИХ ВЧЕНИХ ІЗ ЗАСТОСУВАННЯМ ІНТЕРНЕТ-РЕСУРСІВ БЕЗ ВТРАТИ ВАЛІДНОСТІ
}

\author{
A. Yo. Nakonechnyj, A. R. Vergun, T. I. Nehrych, S. P. Yagelo, I. O. Makahonov, \\ O. M. Vergun, Z. M. Kit, I. V. Shalko \\ Danylo Halytskyi Lviv National Medical University \\ ANTIPLAGIARISM STRATEGY FOR SCIENTIFIC PAPERS \\ EXAMINATION: AUTHOR ALGORITHMS FOR SIMULTANEOUSLY \\ EXPERTISE OF THESES OF REPORTS OF STUDENTS AND YOUNG \\ SCIENTISTS USING ONLINE RESOURCES WITHOUT LOSS OF \\ VALIDITY
}

\begin{abstract}
Мета роботи - оптимізація стратегії первинної технічної антиплагіатної перевірки малооб’ємних публікацій - наукових праць (тез, доповідей на конференції студентів та молодих вчених) зі збільшенням швидкості проведення технічної перевірки без втрати якості ії̈ виконання шляхом впровадження алгоритмів антиплагіатної експертизи наукових праць 3 одномоментною перевіркою декількох тез доповідей без втрати валідності послідовним застосуванням загальнодоступних десктопних програм та інтернет-ресурсів.

Основна частина. Авторами проаналізовано переваги та недоліки програмного забезпечення антиплагіатної експертизи наукових праць, що використовуються у Львівському національному медичному університеті імені Данила Галицького. Запропоновано і впроваджено два алгоритми оптимізації швидкості виконання первинної технічної антиплагіатної перевірки коротких студентських наукових праць без втрати якості її виконання шляхом послідовного та одномоментного застосування десктопних програм “Advego Plagiatus”, “Еtxt Антиплагиат” (“AntiPlagiarism.NET”) й інтернет-ресурсів “Content Watch” та "Be1Ru”. За першим алгоритмом здійснено перевірку 480 тез доповідей студентів та молодих вчених, що були представлені для участі у науковій конференції Львівського національного медичного університету імені Данила Галицького у 2018 р. Внаслідок наявності академічного плагіату відхилено 32 праці (12,8 \%). Перший запропонований алгоритм дозволяє здійснити економію до 75 \% затрат ефективного часу без втрати результативності антиплагіатної первинної технічної експертизи тез доповідей. За іншим алгоритмом здійснена вибіркова перевірка 150 тез доповідей студентської наукової конференції Львівського національного медичного університету імені Данила Галицького. Внаслідок наявності академічного плагіату відхилено 7 праць (4,7 \%). Другий запропонований алгоритм дозволяє здійснити економію 81,11-85,71 \% затрат ефективного часу без втрати результативності антиплагіатної первинної технічної експертизи тез доповідей.

Висновки. Згідно з Положенням про антиплагіатну експертизу та стратегією сприяння академічній доброчесності, нами запропоновано і впроваджено алгоритми оптимізації швидкості виконання первинної технічної антиплагіатної перевірки коротких студентських наукових праць без втрати якості її виконання шляхом послідовного та одномоментного застосування десктопних програм “Advego Plagiatus”, “Etxt Антиплагиат” (“AntiPlagiarism.NET”) й інтернет-ресурсів “Content Watch” та “Be1Ru”. Представлені варіанти оптимізації експертизи з одномоментною перевіркою декількох наукових праць студентів та молодих вчених наукових праць із використанням антиплагіатних інтернет-ресурсів для застосування у наукових відділах вищих навчальних закладів, відділах інформації наукових бібліотек і структурних підрозділах науково-дослідних інститутів та інших навчальних установ, що дозволяє здійснити економію 75-85,71 \% затрат ефективного часу без втрати експертної валідності.
\end{abstract}

Ключові слова: стратегія антиплагіатної експертизи; авторські алгоритми.

The aim of the work - optimization of the strategy of the primary technical antiplagiarism examination of small-scale publications scientific works (theses, reports at the conference of students and young scientists) with an increase in the speed of technical inspection without losing the quality of its implementation by introducing anti-plagiaristic expertise of scientific works with one-step verification of several abstract reports without loss of validity with the use of available desktop programs and Internet resources.

(с) А. Й. Наконечний, А. Р. Вергун, Т. І. Негрич та ін. 
The main body. The authors analyze the advantages and disadvantages of software plagiarism examination of scientific works used at the Danylo Halytskyi Lviv National Medical University. Two algorithms for optimizing the speed of implementation of the primary technical plagiarism verification of short student research papers are proposed and implemented without losing the quality of its implementation by successive and one-time application of the software programs "Advego Plagiatus", "Etxt Antiplagiat” (“AntiPlagiarism. NET") and Internet resources "Content Watch" and "Be1Ru”. According to the first algorithm, 480 theses of reports of students and young scientists submitted for participation in the scientific conference in 2018 of Danylo Halytskyi Lviv National Medical University. 32 works $(12.8 \%)$ were rejected due to the academic plagiarism. The first proposed algorithm allows you to save up to $75 \%$ of the cost of effective time without losing the effectiveness of anti-plagiarized primary technical expertise of theses of reports. Other algorithm carried out random inspection of 150 theses of reports of student scientific conference at Danylo Halytskyi Lviv National Medical University. As a result of academic plagiarism, 7 theses of reports were rejected (4.7\%). The second proposed algorithm allows you to save $81.11 \%-85.71 \%$ of the cost of effective time without losing the effectiveness of anti-plagiarized primary technical expertise of theses of reports.

Conclusions. According to the antiplagiarism examination and the Strategy for Promoting Academic Integrity, we proposed and implemented two algorithms for optimizing the speed of implementation of the primary technical anti-plagiarized verification of short student research papers without losing the quality of its implementation by successive and one-time application of the "Advevego Plagiatus", "Etxt Antiplagiat” (“AntiPlagiarism.NET”) and Internet resources "Content Watch" and "Be1Ru”. Some variants of optimization of examination with one-stage check of several scientific works of students and young scientists with the use of antiplagiarism Internet resources for application in scientific departments of higher educational establishments, departments of information of scientific libraries and structural departments of research institutes and other educational institutions are presented, which allows to realize saving $75 \%-85.71 \%$ of the cost of effective time without loss of expert validity.

Key words: plagiarism expertise strategy; author algorithms.

Вступ. Антиплагіатна експертиза є складовою системи внутрішнього забезпечення якості освітньої діяльності та якості вищої освіти. Експертна оцінка наукових праць $є$ важливою передумовою адекватності реалізації комплексних наукових тем вищих навчальних закладів й об'єктивізує загальну оцінку якості представлення результатів досліджень у фахових та інших наукових виданнях, включаючи тези доповідей наукових конференцій. Відповідно до ст. 32 Закону України “Про вищу освіту” [7], вищі навчальні заклади зобов’ язані вживати заходів, включаючи запровадження відповідних новітніх технологій, для протидії та виявлення плагіату, що є важливою проблемою, яка має не лише юридичний [4-7, 12], але також економічний та соціокультурний контексти $[9,10]$ сприяння академічній доброчесності.

Відповідно до положень Цивільного кодексу України, Закону України “Про вищу освіту”, Закону України “Про авторське право і суміжні права" $[5,6,16]$ та Статуту Університету, з метою запобігання поширенню плагіату в наукових роботах викладацького складу, докторантів, аспірантів, здобувачів наукового ступеня та студентів (зокрема кваліфікаційних робіт магістрів) усіх форм навчання $[1,6,8]$; розвитку навичок коректної роботи із джерелами інформації; дотримання вимог наукової етики та поваги до інтелектуальних надбань [4, 9, 10]; активізації академічної доброчесності, самостійності й індивідуальності при створенні авторського твору і відповідальності за порушення загальноприйнятих правил цитування $[9,11,13]$ нами розроблено типове положення щодо проти- дії академічному плагіату [14]. Академічним плагіатом вважаємо навмисне відтворення (повністю або частково) для виправдання витрачених бюджетних коштів або коштів замовника у друкованій або електронній формі чужого наукового твору, опублікованого на паперовому або офіційно оприлюдненого на електронному носії, привласнення результатів чужої інтелектуальної праці без посилання на автора $[14,16]$. На перший погляд, плагіат не здається настільки серйозною проблемою $[1-3,6$, 9]. Тепер, у контексті академічної доброчесності, більшість провідних вищих навчальних закладів прискіпливіше ставляться до рівня свого престижу і вбачають одним із найважливіших завдань боротьбу з плагіатом. “Репліки” наукових праць та результатів наукових досліджень знижують якість освіти та професійної підготовки фахівців будь-якої галузі [9]. Одним із сучасних напрямків боротьби 3 плагіатом, зокрема академічним, $є$ його виявлення і констатація за допомогою комп'ютерних програм $[1,2,9,11,13,14]$. Задля цього програмне забезпечення (ПЗ) для перевірки робіт на наявність плагіату повинно увесь час удосконалюватись та ставати доступнішим для кінцевого користувача $[2,9,11]$. На сайті Наукової бібліотеки Чернівецького національного університету імені Юрія Федьковича у матеріалі під назвою "Впровадження системи антиплагіату в ЧНУ” [3] представлено 12 видів академічної недоброчесності, зокрема плагіату: “републікація, реплікація, рерайт, фальсифікація, дослівний плагіат, мозаїчний плагіат, відсутність посилань на прямі цитати, неадекватне перефразування, поєднання власного та запозиченого тексту 
без цитування джерел, копіювання чужої наукової роботи та привласнення результатів праці, списування письмових робіт інших студентів, згадування джерел без посилання” [9]. Незважаючи на те, що доповіді про виконані наукові роботи заслуховуються на засіданнях профільних кафедр (лабораторій), враховуючи велику кількість тез доповідей, що скеровуються кафедрами для публікації [4, 13, 15-17], процес їх технічної перевірки стандартним способом (екстенсивним, послідовним) потребує значних затрат часу [14]. Тому актуальною є проблема оптимізації експертизи таких праць шляхом впровадження нових алгоритмів з комплексним застосуванням як онлайн-ресурсів [1, 9, 15, 16], так і десктопного програмного забезпечення [9, 14, 17, 18]. Система запобігання академічному плагіату включає інструкції, процедури та заходи з формування несприйняття академічної нечесності; створення умов, що унеможливлюють академічний плагіат; виявлення копіпастів та реплік у наукових статтях, монографіях, дисертаціях, підручниках, навчальних виданнях; відповідальність за академічний плагіат [16-18]. Антиплагіатна експертиза $є$ невід’ємною складовою системи внутрішньовузівського забезпечення наукової діяльності та якості вищої освіти [2, 3, 11, 14].

Антиплагіатна експертиза здійснюється на підставі Положення, прийнятого та затвердженого на Вченій раді 23.09.2015 р. Застосоване ПЗ для первинної антиплагіатної перевірки є вільнодоступним, рекомендованим у 2016 р. ДАК МОН України [9]. Перевірка тез доповідей та статей у фахові журнали найчастіше здійснюється за допомогою програм “Advego Plagiatus”, “AntiPlagiarism.NET” або “Etxt Антиплагиат” [9, 11, 13, 14]. Проводиться повноцінна поточна перевірка співробітниками наукового відділу публікацій та дисертаційних робіт працівників Львівського національного медичного університету імені Данила Галицького на предмет виявлення академічного плагіату. Особливості первинної експертизи висвітлені у Положенні про протидію академічному плагіату та методичних вказівках. Наявне стандартне вільнодоступне ПЗ, яке застосовується та постійно оновлюється: “Etxt Антиплагіат”, версія 3.72.0.0.,"Etxt Антиплагіат”, версія 4.63.0.0., “AntiPlagiarism.NET”, версія 3.72.1.4., “Advego Plagiatus”, версія 1.3.2.0., “Advego Plagiatus”, версія 1.3.3.2. Тестовані програми: "Praide Unique Content Analyser II", "Shingles Expert”, версія 1.1., “Content Watch”, “BE1RU”,
“Unicheck”. Проведена реєстрація, інсталяція програмних ресурсів, порівняльне тестування на ефективність та доцільність практичного застосування. Працівниками наукового відділу вузу проводяться активні дослідження щодо впровадження сучасного ПЗ та оптимізації проведення перевірки зі збереженням її ефективності та валідності в контексті академічної доброчесності наукових досліджень [1, 2, 11-14, 17, 18]. Після перевірки на плагіат наукової роботи відповідальний експерт надає висновок у вигляді довідки про проведення первинної експертизи з указанням відсотка унікальності (оригінальності) текстових даних у представленій роботі особисто автору або через електронну пошту [14]. Пошук в Інтернеті здійснюється декількома пошуковими системами $[11,13,14,17]$. У результаті візуалізується відсоток оригінальності тексту та список сайтів із відсотком збігу у відповідному кольорі залежно від застосованих пошукових серверів [9, 14, 18].

Мета роботи - оптимізація стратегії первинної технічної антиплагіатної перевірки малооб’ємних публікацій - наукових праць (тез, доповідей на конференції студентів та молодих вчених) зі збільшенням швидкості проведення технічної перевірки без втрати якості їі виконання шляхом впровадження алгоритмів антиплагіатної експертизи наукових праць з одномоментною перевіркою декількох тез доповідей без втрати валідності послідовним застосуванням загальнодоступних десктопних програм та інтернет-ресурсів.

Основна частина. Стратегія антиплагіатної експертизи реалізується шляхом застосування вільнодоступного ПЗ та інтернет-ресурсів. Згідно $з$ внутрішньовузівським Положенням про перевірку результатів наукових досліджень на наявність плагіату, тотальна експертиза проводиться для вільнодоступних, оптимізованих щодо аналізу (незахищених паролем) електронних варіантів тез доповідей, представлених у форматах: *.txt, *.rtf (Rich Text Format), *.doc (Word 97 - Word 2003),*.docx, *.docm (Word 2007-2010), *.pdf (Portable Document Format), *.odf, *.odt (Open Text Document) [14, $17,18]$. Наукова робота вводиться в електронну систему програмного забезпечення антиплагіатної експертизи повністю для визначення загального відсотка унікальності (оригінальності) текстових даних у представленій роботі. Перевірка та пошук збігів виконується по шинглах (методом шинглрозбивки тексту) $[1,2,9,19-21]$. Шингл - структурно-логічний фрагмент тексту, що складається 
3 послідовності декількох слів [14]. Аналіз тексту на копіпаст (копії), рерайт (переписування), пошук плагіату (привласнення) [9, 14] здійснюється за допомогою пошукових систем Google, Yahoo, Bing, Nigma тощо [19, 20, 24].

Факт академічного плагіату у наукових роботах студентів може бути встановлений комісією, створеною розпорядженням декана; у наукових роботах науково-педагогічних працівників, докторантів, аспірантів, здобувачів наукового ступеня - комісією, створеною наказом ректора за поданням проректора з наукової роботи. Відповідальний за автоматичну перевірку наукових текстів та дисертаційних матеріалів вводить текст роботи в електронну систему ПЗ антиплагіатної експертизи і перевіряє її на наявність плагіату.

Виконані не самостійно роботи не можуть бути оцінені позитивно і не допускаються до публікації. Виявлення двох і більше фактів плагіату (компіляцій) у наукових роботах докторантів, аспірантів, здобувачів наукового ступеня може бути підставою для адміністративних санкцій або відрахування [1, 3, 6-9, 14].

Найбільш адекватним ПЗ для експертизи коротких текстів - студентських наукових праць вважається “Advego Plagiatus” [20, 21], версії 1.3.1.7. 1.3.3.2. - безкоштовна програма, якою можна перевірити тези, статтю або будь-який текст на унікальність. За принципом роботи майже не відрізняється від інших антиплагіатних програм, проте працює дещо стабільніше, об’ єктивність пошуку залежить від адекватності налаштувань [1, 9, 11-14]. Одномоментна перевірка 5 тез доповідей реалізується шляхом одномоментного застосування перевірки 3 наукових праць у 3 діалогових вікнах десктопної програми “Advego Plagiatus” [20, 21] та 2 доповідей - в інтернет-ресурсах [22-24] “Content Watch” i “BE1RU” після попередньої реєстрації (Оптимізація антиплагіатної експертизи студентських наукових праць (тез доповідей) шляхом одномоментного послідовного застосування десктопного ПЗ та антиплагіатних інтернет-ресурсів // Рацпропозиція депон. в наук. бібл. Львівського національного медичного університету імені Данила Галицького 26.03.2018 р., свідоцтво № 1913).

При сумнівних результатах перевірки антиплагіатними інтернет-ресурсами (онлайн) здійснюється повторна перевірка цих 2 тез у попередньо відкритих та підготовлених діалогових вікнах “Advego Plagiatus” згідно з запропонованим алгоритмом (рис. 1).
Експертиза 7 наукових праць нами реалізується шляхом десктопного завантаження у попередньо відкриті діалогові вікна вільнодоступного ПЗ [9, 14], скринінгу 5 тез доповідей у 5 діалогових вікнах десктопної програми “Advego Plagiatus” [20, 21] та 2 доповідей - в інтернет-ресурсах “Content Watch” та "Be1Ru” [22, 23] після попередньої реєстрації (Оптимізація антиплагіатної експертизи наукових праць студентів та молодих вчених 3 одномоментною перевіркою 7 тез доповідей з застосуванням антиплагіатних інтернет-ресурсів без втрати валідності // Рацпропозиція депон. в наук. бібл. Львівського національного медичного університету імені Данила Галицького 26.03.2018 р., свідоцтво № 1914).

Загальний текст в “AdvegoPlagiatus” ділиться на фрази, а потім відбувається пошук подібних фраз в Інтернеті через пошукові сервери [14]. Якщо фраза знайдена в Інтернеті, то вона вважається неоригінальною й підсвічується жовтим кольором [20, 21]. Основним недоліком є наявність обмеження тексту до 200000 символів [9, 14]. До можливостей “Advego Plagiatus” відноситься: перевірка в Інтернеті неопублікованих матеріалів; перевірка в Інтернеті опублікованого матеріалу; показ сайтів, на яких знайдені текстові збіги; два ступені перевірки тексту: “Перевірити унікальність” і “Глибока перевірка”; доступна функція: “Прибрати теги”; “підсвічування” неунікальних частин тексту [20]. Програма має вбудований редактор, який містить необхідні базові функції для редагування тексту [21]. В “Advego Plagiatus” є можливість вибирати пошукові системи, швидку або глибоку перевірку, ігнорувати будь-який домен, вибирати та налаштувати кількість слів у пошуковій фразі і розмір шингла, задати у відсотках поріг збігів, перевірити унікальність контенту за визначеною URL-адресою [9]. При сумнівних результатах перевірки антиплагіатними інтернет-ресурсами (онлайн) здійснюється повторна валідизаційна перевірка цих тез у попередньо відкритих та підготовлених діалогових вікнах “Etxt Антиплагиат” (“AntiPlagiarism.NET”) згідно з запропонованим алгоритмом (рис. 2).

У 2017 р. фірмою “Адвего” була розроблена оновлена версія “Advego Plagiatus” - 1.3.3.2, у якій було дещо змінено алгоритми роботи з усіма пошуковими системами, кількість запитуваних пошуковими системами “капч” зменшено в декілька разів, програма використовує весь стандартний “набір” пошукових систем [20, 21]. Оптимізована швидкість роботи сервісу. Вирішено питання з некоректною 


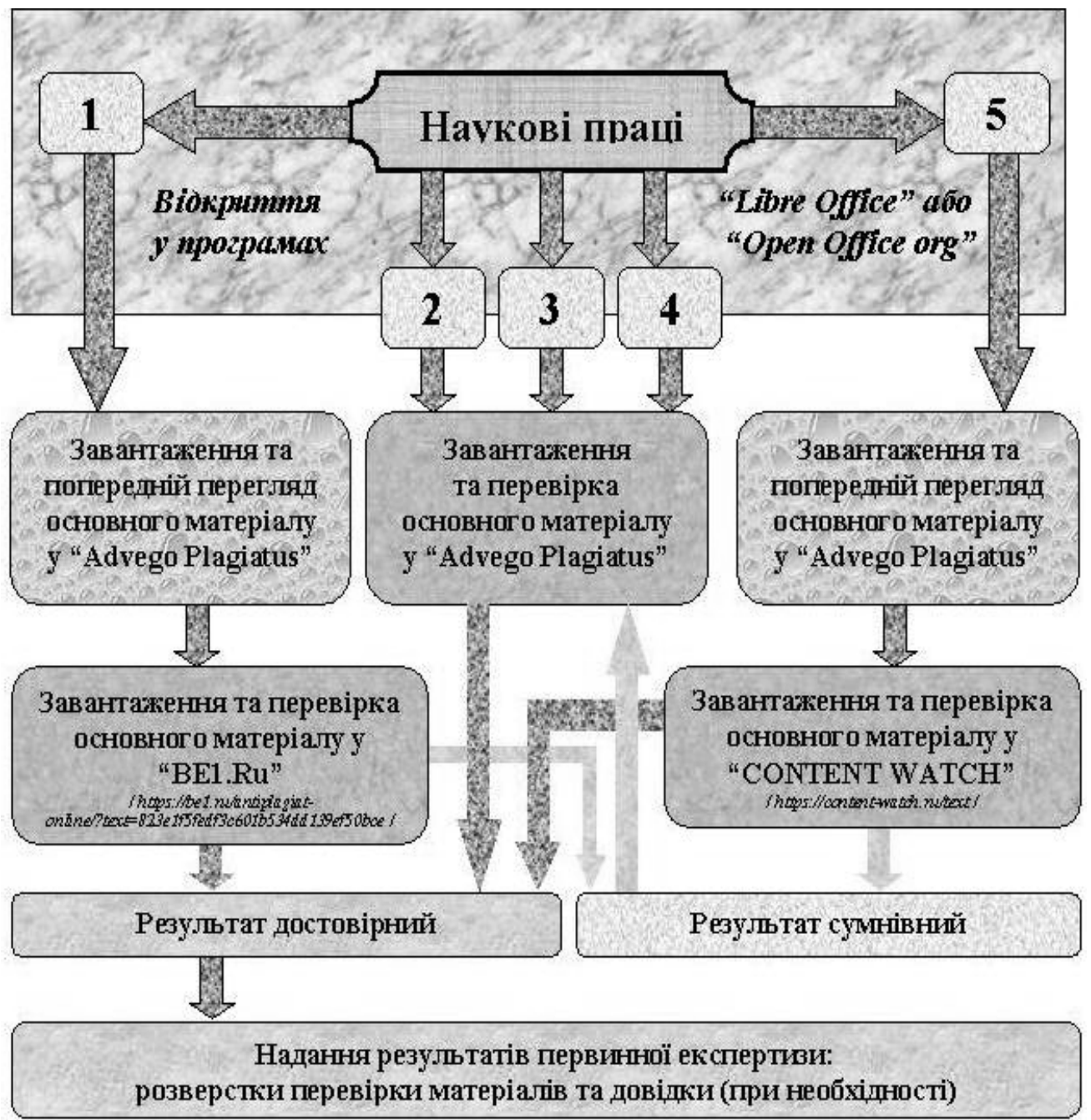

Рис. 1. Авторський алгоритм технічної експертизи 5 наукових праць шляхом одномоментного застосування перевірки 3 тез доповідей у 3 діалогових вікнах десктопної програми “Advego Plagiatus” та 2 - в інтернет-ресурсах “Content Watch” і “BE1RU”.

обробкою деяких капч сервісом “Антігейт”. Змінено дефолтний (він же рекомендований) список пошукових систем [21]. Удосконалений алгоритм пошуку джерел рерайтингу і лексичних збігів. Результатом роботи програми $є$ два параметри: “пошук по фразах” і “пошук за словами” [20]. При появі великої кількості блокувань від системи пошуку Nigma допустиме ії̈ відключення в налаштуваннях [20, 21]. Переривання: “0” (якщо необхідно дізнатися сам факт неунікальності; без докладного вивчення документа, можливо встановити значення рівним “50”). Збіги: від 1 \%. Шингл: 4. Фраза: 4. Таймаут: на швидкому Інтернеті - 10 секунд, на повільному 50 секунд [14, 20]. Нами стверджено, що дані параметри дозволяють застосовувати одночасну перевірку системою до 5 коротких наукових праць (до 20000 символів), - кожної зокрема в окремому діа- логовому вікні [14]. Проте повільність роботи цієї програми детермінує можливість одночасного застосування для паралельної експертизи інших 2 тез доповідей іншими антиплагіатними програмами, включаючи інтернет-ресурси [22-24], оптимальними з яких на сьогодні є “Content Watch" [23] та “Be1Ru” [22]. За допомогою складного алгоритму програмні роботи ділять текст на логічні фрази, онлайн визначають контентні частини та їх авторство. Важливою функцією є виділення кольором і розміром слів, збіг яких у тексті вище $5 \%$. Оптимальним значенням вживання в тексті повторюваних слів (з урахуванням словоформ) прийнято вважати 3-4 \%. У результаті перевірки система надає адекватний звіт подібності, який дозволяє швидко оцінити оригінальність перевіреного тексту, що має значення в контексті стратегії академічної доброчесності. 


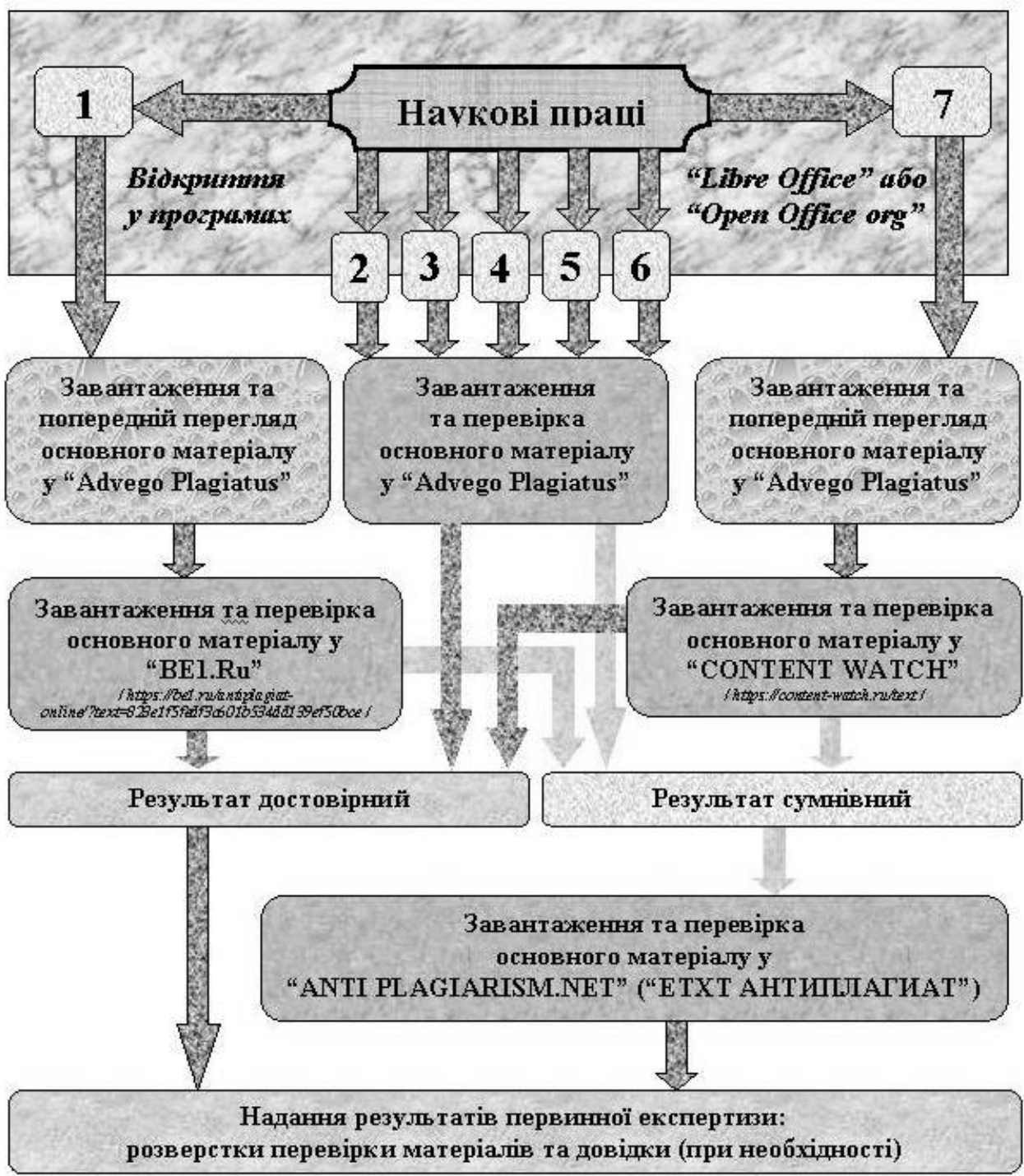

Рис. 2. Авторський алгоритм одномоментної перевірки 7 студентських наукових праць шляхом одномоментного застосування діалогових вікон десктопної програми “Advego Plagiatus” і в інтернет-ресурсах “Content Watch” i “Be1Ru” з валідизаційною перевіркою сумнівних робіт у попередньо відкритих та підготовлених діалогових вікнах “Etxt Антиплагиат” (“AntiPlagiarism.NET”).

Якщо унікальність становить 90-100 \%, то такий текст є повністю унікальний - наявна “еталонна” унікальність контенту [1, 2, 9, 22]. При 80-90 \% текст достатньо унікальний, стверджується добра унікальність контенту. 70-80 \% - текст є допустимо унікальний, наявна нормальна - задовільна унікальність контенту [22]. Для наукових праць допускається 70 \% та вище унікальності тексту [8, 9, 11, 13-15]. При наявності сумнівного результату експертиз (неправдоподібно великого або низького відсотка унікальності) для валідизації результатів сумнівні тези, згідно із запропонованим нами алгоритмом, перепровіряються програмою "Etxt Антиплагиат” (комерційна версія "AntiPlagiarism. NET”) [1, 8, 9, 14, 19]. Програми “Etxt Антиплаги- aт” i “AntiPlagiarism.NET” дозволяють перевіряти написані тексти, всі сторінки потрібного сайта, та вести пакетну перевірку всіх файлів з папки [19]. Для того щоб не здійснювати завантаження файлів по одному, існує пакетна перевірка. Пакетна перевірка дозволяє завантажити до програми “Etxt Антиплагиат” (налаштування програми “Anti Plagiarism.NET” є аналогічним) папку з файлами для одночасної перевірки [9, 14]. Для експертизи тексту потрібно вставити його у віконце сервісу і перевірити на унікальність. Інтерфейс цих програм $€$ зрозумілим і зручним, десктопним ПЗ адекватно розпізнається неунікальний текст $[9,19]$. Недоліки - можливі “зависання” (“AntiPlagiarism.NET”, як комерційна версія, є більш стабільною у роботі) 
[14]. Повільність роботи та достатньо висока частота програмних збоїв не дозволяє застосовувати “Etxt Антиплагиат” для основної перевірки декількох тез доповідей [11, 13, 14], проте дане ПЗ добре зарекомендувало себе для валідизації сумнівних результатів [9], що враховано у нашому алгоритмі.

У рамках комплексної стратегії академічної доброчесності [3-6, 17, 18, 24] й тотальної антиплагіатної експертизи публікацій результатів наукових досліджень нами здійснено перевірку наукових праць - 480 тез доповідей студентів та молодих вчених, що були представлені для участі у науковій конференції Львівського національного медичного університету імені Данила Галицького у 2018 р. Внаслідок наявності академічного плагіату відхилено 32 праці (12,8 \%). Тривалість перевірки одного логічного блоку (5 праць становила 15-25 хвилин). При послідовній перевірці 5 студентських тез стандартним способом десктопною програмою “Advego Plagiatus, версія 1.3.3.2” (80 тез доповідей - група контролю) така перевірка триває до 1 год (4565 хвилин). Таким чином, перший запропонований алгоритм дозволяє здійснити економію до 75 \% затрат ефективного часу без втрати результативності антиплагіатної первинної технічної експертизи тез доповідей. За іншим алгоритмом здійснена вибіркова перевірка 150 тез доповідей студентської наукової конференції Львівського національного медичного університету імені Данила Галицького, внаслідок наявності академічного плагіату відхилено 7 праць (4,7 \%). Тривалість перевірки одного логічного блоку (7 праць) становила 10-17 хвилин, середня тривалість - 12 хвилин. При послідовній перевірці 7 студентських тез стандартним способом десктопною програмою “Advego Plagiatus, версія 1.3.3.2” (80 тез доповідей - група контролю) така перевірка триває до 1,5 год (70-90 хвилин). Таким чином, другий запропонований алгоритм також дозволяє здійснити економію 81,11-85,71 \%

\section{Список літератури}

1. Артамонов Є. Б. Аналіз методів протидії автоматичним системам визначення плагіату в електронних документах / Є. Б. Артамонов // Проблеми інформатизації та управління. - 2012. - № 4 (40). - С. 12-18.

2. Воронкін О. С. Автоматизований текстологічний аналіз: використання детекторів інтернет-плагіату в академічному секторі / O. С. Воронкін // Foss Lviv. -2013. - С. 39-41.

3. Впровадження системи антиплагіату в ЧНУ [Електронний ресурс] / Наукова бібліотека Чернівецького національного університету ім. Ю. Федьковича. - URL : затрат ефективного часу без втрати результативності антиплагіатної первинної технічної експертизи тез доповідей. Наведені результати апробації алгоритму дозволяють рекомендувати алгоритми антиплагіатної експертизи наукових праць студентів та молодих вчених з одномоментною перевіркою декількох тез доповідей та застосуванням антиплагіатних інтернет-ресурсів без втрати експертної валідності для практичного використання у навчальних закладах.

Висновки. Згідно з Положенням про антиплагіатну експертизу та стратегією сприяння академічній доброчесності, нами запропоновано та впроваджено алгоритми оптимізації швидкості виконання первинної технічної антиплагіатної перевірки коротких студентських наукових праць без втрати якості її виконання шляхом послідовного та одномоментного застосування десктопних програм “Advego Plagiatus”, “Etxt Антиплагиат” (“AntiPlagiarism.NET”) й інтернет-ресурсів “Content Watch” та "Be1Ru”. Антиплагіатна перевірка проводиться на засадах сприяння академічній доброчесності з метою розвитку навичок коректної роботи із джерелами інформації; дотримання вимог наукової етики, загальноприйнятих правил цитування та поваги до інтелектуальних надбань; активізації самостійності й індивідуальності виконання наукової роботи. Наведені результати апробації алгоритмів дозволяють рекомендувати комплексні варіанти оптимізації експертизи з одномоментною перевіркою декількох наукових праць студентів та молодих вчених наукових праць із використанням антиплагіатних інтернет-ресурсів для застосування у наукових відділах вищих навчальних закладів, відділах інформації наукових бібліотек та структурних підрозділах науково-дослідних інститутів й інших навчальних установ, що дозволяє здійснити економію 75-85,71 \% затрат ефективного часу без втрати експертної валідності.

http://www.library.chnu.edu.ua/index.php?page=ua/ archive\&data[5008][news_id]=6209.

4. Григоренко А. Збирання доказової бази при порушенні права інтелектуальної власності в мережі Інтернет / А. Григоренко // Інтелектуальна власність. - 2012. № 7. - С. 10-12.

5. Закон України “Про авторське право і суміжні права”// Законодавство України про охорону інтелектуальної власності. Станом на 25 червня 2007 р. / Верховна Рада України. - Офіц. вид. - К. : Парлам. вид-во, 2007. 
6. Ковальова Алла. Проблеми академічного плагіату та авторського права / Алла Ковальова // Спеціальні історичні дисципліни. - 2014. - № 21. - С. 61-71.

7. Кримінальний кодекс України : за станом на 18 грудня 2007 р. / Верховна Рада України. - Офіц. вид. - К. : Парлам. вид-во, 2007.

8. Плагіат у студентських роботах: методи виявлення та запобігання : метод. посіб. / [Н. В. Стукало, К. В. Ковальчук, М. В. Литвин та ін.] ; Дніпропетровський національний університет ім. О. Гончара. - Дніпропетровськ, 2013. - 44 с.

9. Програмне забезпечення для перевірки наукових текстів на плагіат: інформаційний огляд / [автори-укладачі: А. Р. Вергун, Л. В. Савенкова, С. О. Чуканова] ; редколегія: В. С. Пашкова, О. В. Воскобойнікова-Гузєва, Я. Є. Сошинська; Українська бібліотечна асоціація. - К. : УБА, 2016. - Електрон. вид. - електрон. опт. диск (CDROM). - 36 c. - ISBN 978-966-97569-5-4.

10. Романова I. В. “Явище плагіату: історія та сьогодення” / I. В. Романова. - URL : http://www.library.univ. kiev.ua.

11. Харитонова О. І. До визначення системи порушень прав інтелектуальної власності / О. І. Харитонова // Правове життя сучасної України : матеріали Міжнар. наук. конф. професорсько-викладацького складу. Т. 3. - Одеса : Фенікс, 2012. - С. 179-181.

12. Особливості перевірки наукових та навчально-методичних праць у медичному університеті: антиплагіатна експертиза / М. К. Хобзей, А. Р. Вергун, 3. М. Кіт, С. П. Ягело // Сучасні підходи до вищої медичної освіти в Україні (з дистанційним під’єднанням ВМ(Ф)НЗ України за допомогою відеоконференц-зв’язку) : матеріали

\section{References}

1. Artamonov, E.B. (2012). Analiz metodiv protydii avtomatychnoho systemnoho vyznachennia plahiatu $\mathrm{v}$ elektronnykh dokumentakh [Analysis of methods of counteraction to automatic systems of determination of plagiarism in electronic documents]. Problemy informatyzatsii ta upravlinna - Problems of Informatization and Management, 4 (40), 12-18 [in Ukrainian].

2. Voronkin, O.S. (2013). Avtomatyzovanyi tekstolohichnyi analiz: vykorystannia detektoriv internet-plahiatu $\mathrm{v}$ akademichnomu sektori [Automated textual analysis: the use of online plagiarized detectors in the academic sector]. Foss Lviv, 39-41 [in Ukrainian].

3. Vprovadzhennia systemy antyplahiatu v ChNU, elektronnyi resurs [Implementation of antiplagiarism system in ChNU, online resource]. Naukova biblioteka Chernivetskoho natsionalnoho universytetu im. Yu. Fedkovycha - Scientific Library named after Yu. Fedkovych of Chernivtsi National University. - Retrieved from: URL.http://www.library.chnu. edu.ua/index.php?page $=$ ua/archive \&data[5008][news_ id] $=6209$ [in Ukrainian].

4. Hryhorenko, A. (2012). Zbyrannia dokazovoi bazy pry porushenni prava intelektualnoi vlasnosti $\mathrm{v}$ merezhi Internet [Evidence base collection of violation of intellectual
XIV Всеукр. наук.-практ. конф. $з$ міжнар. участю, присвяченої 60-річчю ТДМУ. - Тернопіль : ТДМУ, 2017. T. 2. - С. 173-174.

13. Хобзей М. К. Перевірка наукових праць на наявність академічного плагіату у медичному університеті: основні авторські напрацювання та аналіз півторарічного досвіду функціонування експертизи / М. К. Хобзей, А. Р. Вергун, О. Є. Січкоріз // Південноукраїнський медичний науковий журнал. - 2017. - № 16. - С. 30-36.

14. Чоп'як В. В. Технічна експертиза наукових праць на наявність академічного плагіату (методичні вказівки) / В. В. Чоп’як, О. Б. Надрага, А. Р. Вергун. - Львів, 2016. -49 c.

15. Academic Plagiarism. - URL : http://www.academicplagiarism.com/.

16. Authors' Rights // Wikipedia, the free encyclopedia.URL : http://en.wikipedia.org/wiki/Authors'rights.

17. Harris R. Anti-Plagiarism Strategies for Research Papers / R. Harris. - URL : http://advego-pro.ru/advego-plagiatus. html.

18. Prevalence of Plagiarism Medical Students / L. BiliæZulle, V. Frkoviæ, T. Turk [et al.] // Croat Med. J. - 2005. No. 46 (1). - P. 126-131.

19. URL : https://www.etxt.ru/antiplagiat/.

20. URL : https://advego.com/blog/read/news/3215142/ all1/.

21. URL : http://www.anyaplanet.net/inet/AdvegoPlagiatus.html.

22. URL : https://be1.ru/antiplagiat-online/.

23. URL : https://content-watch.ru/text.

24. URL : http://www.virtualsalt.com/antiplag.htm.

property rights in the Internet]. Intelektualna vlasnist Intellectual Property, 7, 10-12 [in Ukrainian].

5. (2007). Zakon Ukrainy "Pro avtorske pravo i sumizhni prava” [Law of Ukraine “On Copyright and Related Rights”] Zakonodavstvo Ukrainy pro okhoronu intelektualnoi vlasnosti [The Law of Ukraine on Intellectual Property Protection]. Verkhovna Rada Ukrainy. Kyiv. Parlamentske vydavnytstvo - Kyiv. Parliamentary Publishing House. Retrieved from: http://www.intellect.ua/ukr/copyright/law/ laws/copyright [in Ukrainian].

6. Kovaliova, A. (2014). Problemy akademichnoho plahiatu ta avtorskoho prava [Problems of academic plagiarism and law of copyright]. Spetsialni istorychni dystsypliny Special Historical Disciplines, 21, 61-71 [in Ukrainian].

7. Kryminalnyi kodeks Ukrainy: stanom na 20. 05. 2012. [The Criminal Code of Ukraine. 20. 05. 2012]. Verkhovna Rada Ukrainy. Kyiv. Parlamentske vydavnytstvo - Kyiv. Parliamentary Publishing House. - Retrieved from: http:// zakon4.rada.gov.ua/laws/show/2341-14/ed20120520 [in Ukrainian].

8. Stukalo, N.V., Kovalchuk, K.V., \& Lytvyn, M.V. (2013). Plahiat u studentskykh robotakh: metody vyiavlennia ta zapobihannia: metodychnyi posibnyk [Plagiarism in student 
work: methods of detection and prevention: methodical manual]. Dnipropetrovsk: O. Honchar Dnipropetrovsk National University [in Ukrainian].

9. (2016). Prohramne zabezpechennia dlia perevirky naukovykh tekstiv na plahiat: informatsiinyi ohliad [Software for verification of scientific texts on plagiarism: information review]. Authors-compilers: Verhun, A.R., Savenkova, L.V., Chukanova, S.O. Editorial Board: Pashkova, V.S., Voskoboinikova-Huzeva, O., Soshynska, Ya.E. Kyiv: Ukrainian Library Association. CD-ROM, ISBN 978-966-97569-5-4 [in Ukrainian].

10. Romanova, I.V. (2014). Yavyshche plahiatu: istoriia ta siohodennia [The phenomen of plagiarism: history and present]. - Retrieved from: http://www.library.univ.kiev. ua [in Ukrainian].

11. Kharytonova, O.I. (2012). Do vyznachennia systemy porushen prav intelektualnoi vlasnosti [To the definition of the system of intellectual property rights violations]. Pravove zhyttia suchasnoi Ukrainy: materialy mizhnarodnoi naukovoi konferentsii profesorsko-vykladatskoho skladu Legal Life of Modern Ukraine: Materials of the International Teaching Scientific Conference. Odesa: Phoenix [in Ukrainian].

12. Khobzei, M.K., Verhun, A.R., Kit, Z.M., \& Yahelo, S.P. (2017). Osoblyvosti perevirky naukovykh ta navchalnometodychnykh prats u medychnomu universyteti: antyplahiatna ekspertyza [Features of scientific and teachingmethodical works examination at medical university: antiplagiarism expertise]. Suchasni pidkhody do vyshchoi medychnoi osvity $v$ Ukraini (z dystantsiinym pidiednanniam VM(F)NZ Ukrainy za dopomohoiu videokonferents-zviazku): materialy XIV Vseukr. nauk.-prakt. konf. z mizhnar. uchastiu, prysviachenoi 60-richchiu TDMU-Modern Approaches to Higher Medical Education in Ukraine (with remote connection of $V M(F) N Z$ of Ukraine with the help of videoconferencing): materials of XIVAll-Ukrainian scientific and practical conference with international participation devoted to the 60th of TDMU. Ternopil: TDMU [in Ukrainian].

13. Khobzei, M.K., Verhun A.R., \& Sichkoris, O.Ye. (2017). Perevirka naukovykh prats na naiavnist akademichnoho plahiatu u medychnomu universyteti: osnovni avtorski napratsiuvannia ta analiz pivtorarichnoho dosvidu funktsionuvannia ekspertyzy [Verification of scientific works for the presence of academic plagiarism at the medical university: the main author's work and analysis of a half year experience of the examination]. Pivdennoukrainskyi medychnyi naukovyi zhurnal - South Ukrainian Medical Journal, 16, 30-36 [in Ukrainian].

14. Chopiak, V.V., Nadraha, O.B., \& Verhun, A.R. (2016). Tekhnichna ekspertyza naukovykh prats na naiavnist akademichnoho plahiatu (metodychni vkazivky) [Technical examination of scientific works on the presence of academic plagiarism. Methodical instructions]. Lviv: LNMU [in Ukrainian].

15. Academic Plagiarism. - Retrieved from: http://www. academicplagiarism.com/.

16. Authors' Rights // Wikipedia, the free encyclopedia. Retrieved from: http://en.wikipedia.org/wiki/Authors'rights.

17. Harris, R. Anti-Plagiarism Strategies for Research Papers. - Retrieved from: http://advego-pro.ru/advegoplagiatus.html.

18. Biliæ-Zulle, L., Frkoviæ, V., \& Turk, T. (2005). Prevalence of plagiarism medical students. Croat Med. J., 46 (1), 126-131.

19. Retrieved from: https://www.etxt.ru/antiplagiat/.

20. Retrieved from: https://advego.com/blog/read/news/ 3215142/all1/.

21. Retrieved from: http://www.anyaplanet.net/inet/ AdvegoPlagiatus.html.

22. Retrieved from: https://be1.ru/antiplagiat-online/.

23. Retrieved from: https://content-watch.ru/text.

24. Retrieved from: http://www.virtualsalt.com/antiplag. htm.

Отримано 03.04.18

Електронна адреса для листування: plagiamail@meta.ua 